Vol. 1 No. 2 Desember 2021, e-ISSN : 2807-8667| p-ISSN : 2807-8837

\title{
PENGEMBANGAN MEDIA PEMBELAJARAN BOARD GAME MATEMATIKA KELAS VIII SEMESETER 1 KURIKULUM 2013 DI SMP NEGERI 48 JAKARTA
}

\author{
DANANG HADI NUGROHO \\ Pascasarjana PMIPA, Universitas Indraprasta PGRI, Jakarta \\ e-mail: dhnugroho24@gmail.com
}

\begin{abstract}
ABSTRAK
Perkembangan dunia teknologi pada saat ini memberikan pengaruh serta dampak yang Tujuan dari penelitian ini adalah (1) Menghasilkan produk media board game matematika materi pokok semester 1 kurikulum 2013 untuk peserta didik kelas VIII SMP Negeri 48 Jakarta. (2) Mengetahui keefektifan produk media board game matematika materi pokok semester 1 kurikulum 2013 untuk peserta didik kelas VIII SMP Negeri 48 Jakarta. Model pengembangan yang digunakan adalah model Reseach and Development (R\&D) karena pengembangan $R \& D$ memiliki langkah-langkah yang lebih sistematis dan terperinci disetiap tahapannya. Teknik analisis data pada penelitian ini menggunakan angket, wawancara terstruktur dan tes untuk mengetahui kelayakan media. Untuk mengetahui tingkat efektifitas menggunakan teknik analisis uji t sedangkan untuk kelayakan teknik analisis guttman. Data kelayakan produk yang dihasilkan, ditentukan melalui analisis hasil validasi ahli materi $100 \%$ yang termasuk dalam kategori sangat baik, ahli media yaitu 93,33\% dimana juga termasuk dalam kategori sangat baik, ahli desain pembelajaran yaitu $87,5 \%$ yang termasuk dalam kategori sangat baik, ahli bahan penyerta yaitu $95 \%$ yang termasuk dalam kategori sangat baik. Uji coba yang dilakukan baik uji coba perorangan menilai $91,11 \%$ termasuk dalam kategori sangat baik, uji coba kelompok kecil menilai 83,33\%, sedangkan uji kelompok besar 94,4\% dan semua termasuk dalam kategori sangat baik. Dari semua penilaian dan kategori yang sudah dinilai maka dapat disimpulkan bahwa Pengembangan board game matematika materi pokok semester 1 kurikulum 2013 untuk peserta didik kelas VIII SMP Negeri 48 Jakarta, layak untuk digunakan oleh peserta didik. dan ahli media serta uji coba produk perorangan, kelompok kecil, hingga kelompok besar mendapatkan kategori yang sangat baik, sehingga media board game layak untuk diterapkan dalam pembelajaran matematika materi pokok semester 1 kelas VIII kurikulum 2013 dalam kehidupan sehari-hari. Sedangkan hasil analisis data uji t dan peneliti dapat menyimpulkan bahwa hasil rata-rata uji coba posttest yaitu 83,52 lebih tinggi dibandingkan dengan hasil rata-rata pre-test yaitu 56,17. Melalui perhitungan uji t diketahui hasil thitung sebesar 15,337. Selain itu, berdasarkan pengujian menggunakan taraf signifikan $5 \% \mathrm{db}=34-1=33$ diperoleh ttabel $=2,034$. Jadi peneliti dapat menyimpulkan bahwa thitung lebih besar dari ttabel yaitu 15,337>2,034. Sehingga terjadi perbedaan yang signifikan antara pre-test dan post-test dan dapat disimpulkan bahwa media board game efektif digunakan pada pembelajaran matematika materi pokok semester 1 kurikulum 2013 untuk peserta didik kelas VIII SMP Negeri 48 Jakarta.
\end{abstract}

Kata Kunci: Pengembangan, Media board game, Matematika, Materi pokok semester 1 kurikulum 2013.

\section{ABSTRACT}

The development of the world of technology at this time has an influence and impact. The objectives of this research are (1) To produce a board game media product for mathematics, the subject matter of semester 1 of the 2013 curriculum for class VIII students of SMP Negeri 48 Jakarta. (2) To determine the effectiveness of the board game media product, the subject matter of the first semester of the 2013 curriculum for class VIII students of SMP Negeri 48 Jakarta. The development model used is the Research and Development (R\&D) model because R\&D development has more systematic and detailed steps at each stage. The data analysis technique in this study used a questionnaire, structured interviews and tests to determine the feasibility of the media. To determine the level of effectiveness using the $t$ test analysis technique while for 
the feasibility of the Guttman analysis technique. The product feasibility data is determined through the analysis of the results of the validation of the material expert $100 \%$ which is included in the very good category, the media expert is $93.33 \%$ which is also included in the very good category, the learning design expert is $87.5 \%$ which is included in the very good category. good, the expert of the accompanying material is $95 \%$ which is included in the very good category. The trials that were carried out were both individual trials assessed that $91.11 \%$ was included in the very good category, small group trials assessed $83.33 \%$, while large group trials were $94.4 \%$ and all were included in the very good category. From all the assessments and categories that have been assessed, it can be concluded that the development of a mathematical board game for the first semester of the 2013 curriculum for class VIII students of SMP Negeri 48 Jakarta, is suitable for use by students. and media experts as well as individual product trials, small groups, and large groups get a very good category, so that the board game media is feasible to be applied in learning mathematics, the subject matter of semester 1 class VIII curriculum 2013 in everyday life. Meanwhile, the results of the t-test data analysis and the researcher can conclude that the average result of the posttest trial is 83.52 , which is higher than the average result of the pre-test, which is 56.17. Through the t-test calculation, it is known that the t-count result is 15.337 . In addition, based on testing using a significant level of $5 \% \mathrm{db}=34-1=33$, it was obtained ttable $=2.034$. So the researcher can conclude that tcount is greater than ttable, namely $15.337>2.034$. So that there is a significant difference between the pre-test and post-test and it can be concluded that the board game media is effectively used in learning mathematics for the first semester of the 2013 curriculum for class VIII students of SMP Negeri 48 Jakarta.

Keywords: Development, board game media, Mathematics, subject matter for semester 1 of 2013 curriculum.

\section{PENDAHULUAN}

Matematika merupakan salah satu mata pelajaran yang berperan penting dalam kehidupan manusia. Acharya (2017) menyatakan bahwa "Mathematics is the one of the most importance subject in our human life". Oleh karena itu, matematika perlu dipahami oleh peserta didik dari jenjang pendidikan dasar sampai pendidikan tinggi. Matematika merupakan salah satu mata pelajaran yang menekankan konsep. Rahaju dan Hartono (2015) menyatakan bahwa pembelajaran matematika sering difokuskan pada pemberian sejumlah konsep. Menurut Rohana, Hartono, dan Purwoko (2009), penguasaan konsep siswa pada mata pelajaran matematika masih lemah bahkan

Di SMP Negeri 48 Jakarta walaupun setiap hari selalu menulis dan mengerjakan materi dalam pelajaran matematika akan tetapi masih banyak yang belum paham pada materi tersebut karena tidak adanya media lain (selain buku paket, LKPD maupun lembar kerja siswa (LKS)) yang mendukung proses pembelajaran sehingga peserta didik cepat merasa bosan dan pembelajaran menjadi kurang menyenangkan, selain itu tingkat penguasaan mencongak atau berhitung dasar masih kurang dan media untuk praktek matematika belum memadai. Oleh karena itu untuk meningkatkan kualitas pendidikan yang lebih baik maka perlu media untuk mendukung jalannya proses pembelajaan. Media pembelajaran disini membantu peserta didik agar proses pembelajaran menjadi lebih baik, lebih cepat dan lebih banyak. Dikutip dari salah satu pakar ahli yaitu (miarso, 2004) juga mengutarakan pendapatnya bahwa "media adalah suatu hal yang dipakai untuk merangsang pikiran, kemauan dan perhatian peserta didik untuk mendorong kegiatan belajar".

Berdasarkan hasil wawancara dan observasi pada tanggal 20 Maret 2020 dengan guru kelas VIII di SMP Negeri 48 Jakarta peneliti menemukan beberapa permasalahan. Berikut adalah permsalahan yang diperoleh peneliti: (1) Media pembelajaran yang dimiliki hanyalah buku paket, LKPD dan Lembar Kerja Siswa (LKS) saja dan tidak semua memiliki LKS, (2) Proses penyampaian materi hanya menggunakan metode ceramah, (3) Terbatasnya penggunaan media dalam pmbelajaran menyebabkan tingkat peningkatan hasil belajar kurang, (4) Rata-rata 
nilai Matematika kelas VIII di SMP Negeri 48 Jakarta masih dibawah KKM 78 yaitu sekitar 8 anak yang memenuhi KKM, (5) Karakteristik kelas VIII di SMP Negeri 48 Jakarta rata-rata berusia 13-15 tahun dimana sudah mampu berpikir abstrak dan logis dengan menggunakan pola berpikir karena anak SMP kelas VIII rata-rata berumur 13-14 tahun dan anak-anak sudah mampu memahami bentuk argumen dan tidak dibingungkan oleh sisi argument dan gaya belajar lebih mengarah kearah gaya belajar visual-verbal sehingga akan memahami materi dari guru dengan baik apabila menggunakan media visual-verbal, (6) Rata-rata peserta didik berasal dari kalangan menengah kebawah.

Untuk memecahkan permasalahan tersebut maka dibutuhkannya media pembelajaan. Dan tidak semua media dapat digunakan sebagai media pembelajaran maupun diterapkan pada semua mata pelajaran akan tetapi media yang akan peneliti buat ini berupa media board game matematika materi pokok semester 1 kurikulum 2013 untuk peserta didik kelas VIII yang diberikan guru kepada peseta didik. Penggunaan media board game dengan proses belajar peserta didik harus sesuai dengan, karakteristik materi, karakteristik, tujuan pembelajaran, pengalaman dan tingkat kemampuan peserta didik.

Asosiasi Pendidikan Nasional dalam Kristanto (2010) mendefinisikan media dalam lingkup pendidikan sebagai segala benda yang dapat dimanipulasi, dilihat, didengar, dibaca atau dibicarakan beserta instrumen yang dipergunakan untuk kegiatan tersebut. Menurut Newby dalam Kristanto (2011) media pembelajaran adalah segala sesuatu yang dapat membawa pesan untuk pencapaian tujuan pembelajaran. Menurut Kristanto (2016) media pembelajaran adalah segala sesuatu yang dapat digunakan untuk menyalurkan pesan, sehingga dapat merangsang perhatian, minat, pikiran, dan perasaan mahasiswa dalam kegiatan belajar untuk mencapai tujuan. belajar. According to Kristanto (2017) learning media is anything that can be used to channel the message, so it can stimulate the attention, interest, thoughts, and feelings of students in learning activities to achieve learning objectives. According to Kristanto (2018) learning media is anything that can be used to channel the message to achieve learning objectives. According to Kristanto (2019) Media can be defined from its technology, symbol systems and processing capabilities. The characteristics of the most prominent medium are the technology, the mechanical and electrical aspects that determine its function, and in certain cases concerning other physical forms and appearance.

Menurut (Lely Tobing dalam Setyanugrah dan Denny Indrayana Setyadi, 2017) mengatakan bahwa "Board game mampu mengajarkan banyak hal. Board game juga dapat melatih konsentrasi dan daya ingat anak. Untuk anak usia sekolah, boardgame dapat melatih anak memecahkan masalah, berstrategi, serta berpikir kreatif dan kritis". Dengan media board game ada tiga aspek yang tercakup di dalamnya, yaitu aspek visual (gambar), audio (berdiskusi dan tanya jawab), serta afektif (sikap).

Menurut (Mike Scorviano dalam Wirawan dan Ismi Yunita A, 2017) "Dalam sejarah board game dan Psikologi Permainan, board game adalah dimana alat-alat atau bagian-bagian permainan ditempatkan, dipindahkan atau digerakkan pada permukaan papan permainan yang telah ditandai atau dibagi-bagi menurut seperangkat aturan permainan tersebut”.

Berdasarkan latar belakang masalah tersebut, maka diperlukan Pengembangan Media Board Game Matematika Materi Pokok Semester 1 Kurikulum 2013 Untuk Peserta Didik Kelas VIII SMP Negeri 48 Jakarta.

\section{METODE PENELITIAN}

ODE Dalam pengembangan media board game, pengembang memilih metode penelitian R\&D (Research and Development). Metode penelitian pengembangan R\&D (Borg and Gall) merupakan metode yang digunakan untuk menghasilkan produk tertentu menguji keefektifan dan kelayakan produk tersebut (dalam Sugiyono, 2013).

Dalam Sugiono (2013: 408) menjelaskan langkah-langkah penelitian pengembangan R\&D (Borg and Gall) yang meliputi, (1) potensi dan masalah, (2) pengumpulan data, (3) desain produk, (4) validasi media, (5) revisi desain, (6) ujicoba produk, (7) revisi produk, (8) ujicoba 
produk, (9) revisi produk, (10) produksi massal. Langkah-langkah prosedural pada penelitian ini dilakukan secara bertahap sebagaimana yang ditunjukkan ppada gambar dibawah ini:

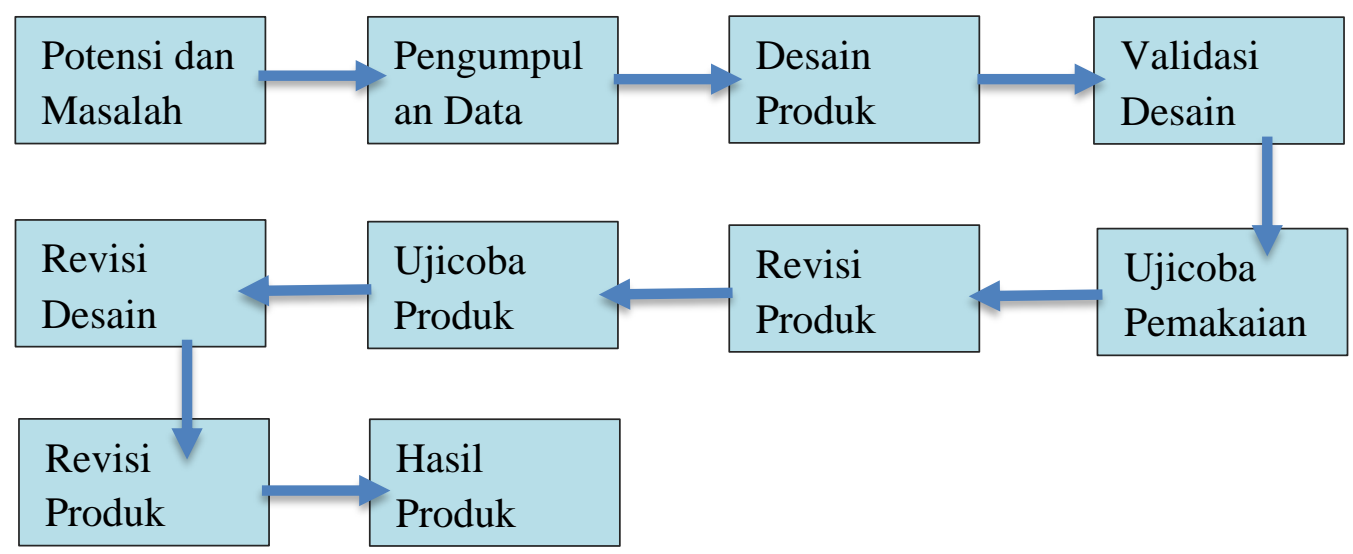

\section{Gambar 1. Langkah-langkah penggunaan metode Research and Development (R\&D) Borg and gall 1989 dalam Sugiyono (2013).}

Subjek uji coba dalam penelitian ini yaitu peserta didik kelas VIII SMP Negeri 48 Jakarta yang berjumlah 34 orang. Dengan menggunakan kelompok kontrol dan kelompok eksperimen 1 kelas. Kelompok kontrol yaitu kelompok yang tidak diberi perlakuan (Tidak menggunakan media) sedangkan kleompok eksperimen yaitu yang diberi perlakuan (menggunakan media). Desain penelitian menggunakan One Group Pre-test dan Post-test.

Jenis data penelitian pengembangan ini menggunakan data kualitatif dan data kuantitatif. Data kualitatif diperoleh dari masukan, tanggapan, saran, dan kritik dari ahli materi, media, RPP dan bahan penyerta untuk selanjutnya dianalisis dan digunakan dalam proses revisi media. sedangkan data kuantitatif merupakan data yang berpa angka statistik yang diperoleh dari hasil uji coba ahli materi, ahli meedia, RPP dan bahan penyerta, uji coba perorangan, uji coba kelompok kecil, dan uji coba kelompok besar.

Dalam penelitian pengembangan media board game ini, terdapat beberapa instrumen pengumulan data yang digunakan diantaranya yaitu, observasi, wawancara, angket, tes dan dokumentasi.

Instrumen pengumpulan data dalam penelitian ini menggunakan skala ukur Guttman. Skala Guttman memberikan dua pilihan jawaban yaitu "setuju" atau "tidak setuju".

Berikut skala pengukurannya:

$\mathrm{A}=$ skor 1 untuk jawaban setuju

$\mathrm{B}=$ skor 0 untuk jawaban tidak setuju

Analisis isi dilakukan pada hasil uji coba produk kepada ahli media, materi, RPP dan bahan penyerta. Data kualitatif yang diperoleh berupa tanggapan, saran dan perbaikan. Dari hasil data tersebut kemudian dikelompokkan serta dianalisis untuk perbaikan produk. Dalam penelitian ini menggunakan teknik analisis data yaitu teknik perhitungan Guttman.

Perhitungan persentase dari setiap aspek pada variabel yang terdapat pada media yang dievaluasi. Adapun rmus peerhitungannya sebagai berikut:

$$
\mathrm{P}=\frac{f}{N \times n} \times 100 \%
$$

\section{Keterangan:}

$\mathrm{P} \quad=$ Presentase

$\mathrm{F} \quad=$ Frekwensi dari setiap jawaban yang sudah menjadi pilihan responden

$\mathrm{N} \quad=$ Jumlah responden 
$\mathrm{n}$ $=$ Jumlah Butir Soal

Sedangkan untuk perhitungan prosentase menurut Arikunto (2010) pada semua apsek yang mempunyai kesamaan yang akhirnya menjadi suatu penilaian yang mengacu pada kriteria penilaian yang telah ditentukan.

Tabel 1. Tabel Kriteria Penilaian

\begin{tabular}{|l|l|}
\hline Tingkat Pecapaian & Keterangan \\
\hline $81-100$ & Sangat Baik \\
\hline $61-80$ & Baik \\
\hline $41-60$ & Kurang Baik \\
\hline $21-40$ & Tidak Baik \\
\hline $0-20$ & Sangat Tidak Baik \\
\hline
\end{tabular}

Data tes yang diperoleh dari pengembangan ini menggunakan skala interval dengan menggunakan rumus statistik Uji-t menurut Arikunto (2013) untuk membandingkan kedua mean. Pengujian mean dihitung dengan rumus t-test sebagai berikut:

$$
t=\frac{M d}{\sqrt{\frac{\sum x^{2} d}{N(N-1)}}}
$$

Keterangan :

$\mathrm{Md}=$ Nilai rata-rata (mean) dari perbedaan pre-test dan post-test (post-test - pre-test)

$\mathrm{Xd}=$ perbedaan deviasi dan mean deviasi

$\mathrm{X}^{2} \mathrm{~d}=$ jumlah kuadrat deviasi

$\mathrm{N}=$ banyaknya subyek

df atau d.b : N-1

\section{HASIL DAN PEMBAHASAN}

Guru matematika yang mengajar di sekolah menengah pertama harus memiliki kompetensi dalam menciptakan suasana belajar yang menyenangkan bagi peserta didiknya. Dimana kreativitas untuk menyampaikan materi matematika yang dianggap rumit perlu dimiliki oleh seorang guru matematika supaya peserta didik tidak menjadikan pelajaran matematika menjadi momok yang menakutkan.

Dari hasil pengamatan peneliti yang dilakukan selama menjadi guru magang di SMP Negeri 48 Jakarta, peneliti menemukan masalah yang dihadapi oleh guru SMP Negeri 48 Jakarta terutama guru matematika kelas VIII yaitu kesulitan ketika menyampaikan materi matematika semester 1 kurikulum 2013 salah satunya adalah persamaan garis dan relasi fungsi.

Kemudian peneliti melakukan wawancara dan observasi pada tanggal 20 Maret 2020 dengan guru kelas VIII di SMP Negeri 48 Jakarta peneliti menemukan beberapa permasalahan. Berikut adalah permsalahan yang diperoleh peneliti: (1) Media pembelajaran yang dimiliki hanyalah buku paket, LKPD dan Lembar Kerja Siswa (LKS) saja dan tidak semua memiliki LKS, (2) Proses penyampaian materi hanya menggunakan metode ceramah, (3) Terbatasnya penggunaan media dalam pmbelajaran menyebabkan tingkat peningkatan hasil belajar kurang, (4) Rata-rata nilai Matematika kelas VIII di SMP Negeri 48 Jakarta masih dibawah KKM 78 yaitu sekitar 8 anak yang memenuhi KKM, (5) Karakteristik kelas VIII di SMP Negeri 48 Jakarta rata-rata berusia 13-15 tahun dimana sudah mampu berpikir abstrak dan logis dengan menggunakan pola berpikir karena anak SMP kelas VIII rata-rata berumur 13-14 tahun dan anak-anak sudah mampu memahami bentuk argumen dan tidak dibingungkan oleh sisi argument dan gaya belajar lebih mengarah kearah gaya belajar visual-verbal sehingga akan 
memahami materi dari guru dengan baik apabila menggunakan media visual-verbal, (6) Ratarata peserta didik berasal dari kalangan menengah kebawah.

Oleh sebab itu peneliti ingin membuat suatu media pembelajar agar peserta didik kelas VIII SMP Negeri 48 Jakarta memilki semangat belajar matematika dan memahami matematika dengan cara yang baru yang lebih menyenangkan.

\section{Hasil}

Dalam tahap ini peneliti melakukan observasi dan wawancara terhadap guru mata pelajaran terkait permasalahan pembelajaran. Permasalahan dan kesulitan dalam proses pembelajaran tesebut yang menjadi potensi dan masalah. Pada mata pelajaran matematika materi pokok semester 1 kelas VIII semester 1 SMP Negeri 48 Jakarata sulit untuk dipahami terutama masalah memahami persamaan garis lurus serta belum adanya media yang mendukung pembelajaran. Pembelajaran masih bersifat konvensional. Serta penggunaan media pembelajaran yang kurang efektif dan efisien. Dalam materi pokok persamaan garis lurus, proses pembelajaran belum didukung dengan media untuk melatih proses pengetahuan titik koordinat dan persamaan garis yang tepat. Karena pada materi ini hanya menggunakan buku paket sebagai media penyampai informasi dan pembelajaran.

1. Pengumpulan Data

Setelah melakukan tahapan potensi dan masalah melalui observai maupun wawancara, maka tahap seelanjutnya yaitu pengumpulan data dengan cara memperbanyak studi pustaka mulai dari tujuan pembelajaran.

2. Desain Produk

a. Desain Produk Materi

Pada tahap ini dlakkannya pengumpulan informasi atau materi dari berbagai sumber baik dar guru mata pelajaran matematika, buku paket, LKPD dan internet. Konsultasi kepada guru mata pelajaran dilakukan terkait materi yang akan dikembangkan pada media board game.

b. Desain Produk Media Board Game

Hasil Produk dari pengembangan ini adalah media pembelajaran yang berupa media tiga dimensi yang berupa Board Game agar membantu guru memecahkan masalah belajar peserta didik dan untuk meningkatkan hasil belajar peserta didik pada indikator mata pelajaran matematika di SMP Negeri 48 Jakarta.

Spesifikasi produk dalam pengembangan ini meliputi :

1. Berbentuk papan catur yang dapat dilipat berukuran $60 \times 60 \mathrm{~cm}$.

2. Di dalamnya terdapat dadu, kartu pertanyaan, kartu petunjuk, karakter permainan dan uang mainan.

3. Bahan baku yang digunakan terbuat dari kertas tebal yang tahan air dan terdapat dua permukaan sisi gama monopoly dan ular tangga koordinat.

4. Kartu petunjuk terdapat suatu tata cara petunjuk mengerjakan soal dan petunjuk lain yang menginturksikan arah permainan.

5. Terdapat 100 kolom untuk ular tangga cartecius dan 42 kotak gama monopoly yang didalamnya terdapat landmark dari kota yang ada di Indonesia.

c. Desain Produk Bahan Penyerta

Pada tahap ini pengembang membuat desain cover bahan penyerta dan layout isi bahan penyerta yang diolah dengan menggunakan software Corel Draw X7. Bahan penyerta merupakan buku panduan atau buku petunjuk yang berisi identifikasi program, prosedur penggunaan, petunjuk pengunaan, tata cara bermain board game, perawatan media, serta RPP. 
3. Validasi Desain

Validasi desain merupakan proses untuk menilai rancangan produk agar dapat diketahui kelemahan dan kekuatan produk board game. Validasi desain dilakukan oleh 2 orang ahli materi yaitu orang berkompeten serta menguasai dibidang mata pelajaran Matematika, validasi desain dilakukan oleh 2 orang ahli media yaitu orang berkompeten serta menguasai dibidang media pembelajaran, validasi desain dilakukan oleh 2 orang ahli bahan penyerta yaitu orang berkompeten serta menguasai dibidang desain media dan validasi desain pembelajaran (RPP) dilakukan oleh 1 orang ahli desain pembelajaran yaitu orang berkompeten serta menguasai dibidang desain pembelajaran (RPP).

4. Revisi Desain

Setelah produk media divalidasi oleh beberapa ahli dan menemukan kelemahan desain produk tersebut, maka dilakukan revisi desain untuk memperbaiki desain produk yang akan dihasilkan. Tahap ini dilakukan berdasarkan saran yang diperoleh dari ahli materi dan ahli media pada angket validasi. Dari ahli materi mendapat saran sebagai berikut:

a. Bahasa didalam pertanyaan dibuat dengan bahasa yang lebih baku.

b. Papan Board Game dibuat lebih menarik dengan warna yang lebih bervariatif dan berisi landmark dis etiap kota yang ada di Indonesia.

c. Keping huruf dalam media board game sudah disesuaikan dengan aturan main yang sudah ditetapkan.

Sedangkan oleh ahli media mendapatkan saran sebagai berikut:

a. Sebaiknya ada tulisan seperti Board Game Gama disamping stiker board game untuk menunjukkan itu adalah media board game Matematika.

b. Warna Cover dan background bahan penyerta juga disamakan dengan warna media board game supaya selaras dan tulisan untuk SD/MI diganti SMP.

c. Profil diperbaiki dengan ditambahkan identitas lebih lengkap

d. Untuk format font kartu pertanyaan menggunakan font Arial 12 Hitam dengan background putih

e. Cover depan kartu pertanyaan dan petunjuk di buat desain dengan warna berbeda dengan ukuran $5 \times 4 \mathrm{~cm}$.

Untuk penyempurnaan desain produk, maka pada tahap ini pengembang telah memperbaiki sesuai dengan saran ahli media dan berikut ini adalah gambar hasil revisi:
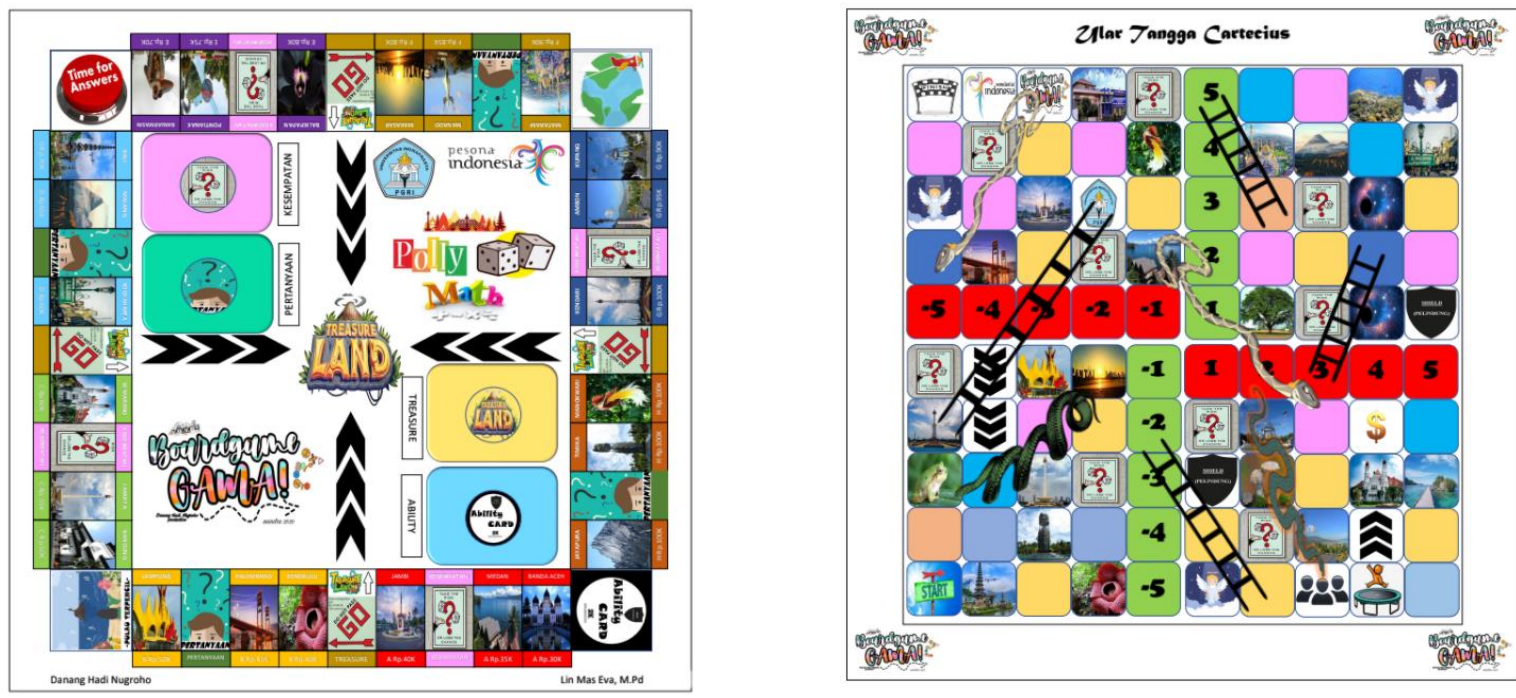

Gambar 2. Tampilan Desain Boardgame 
Vol. 1 No. 2 Desember 2021, e-ISSN : 2807-8667| p-ISSN : 2807-8837

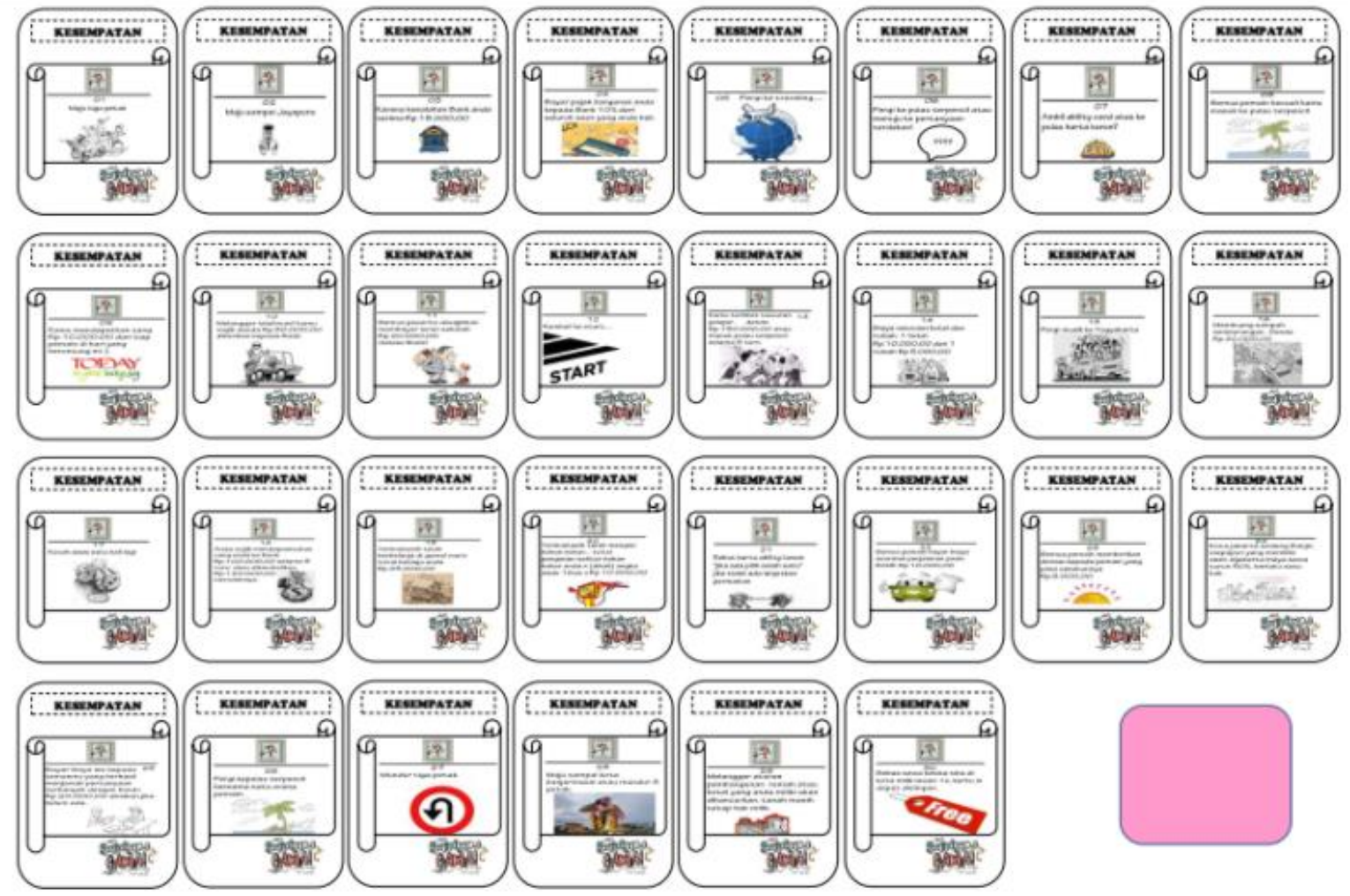

Gambar 3. Tampilan Kartu Kesempatan
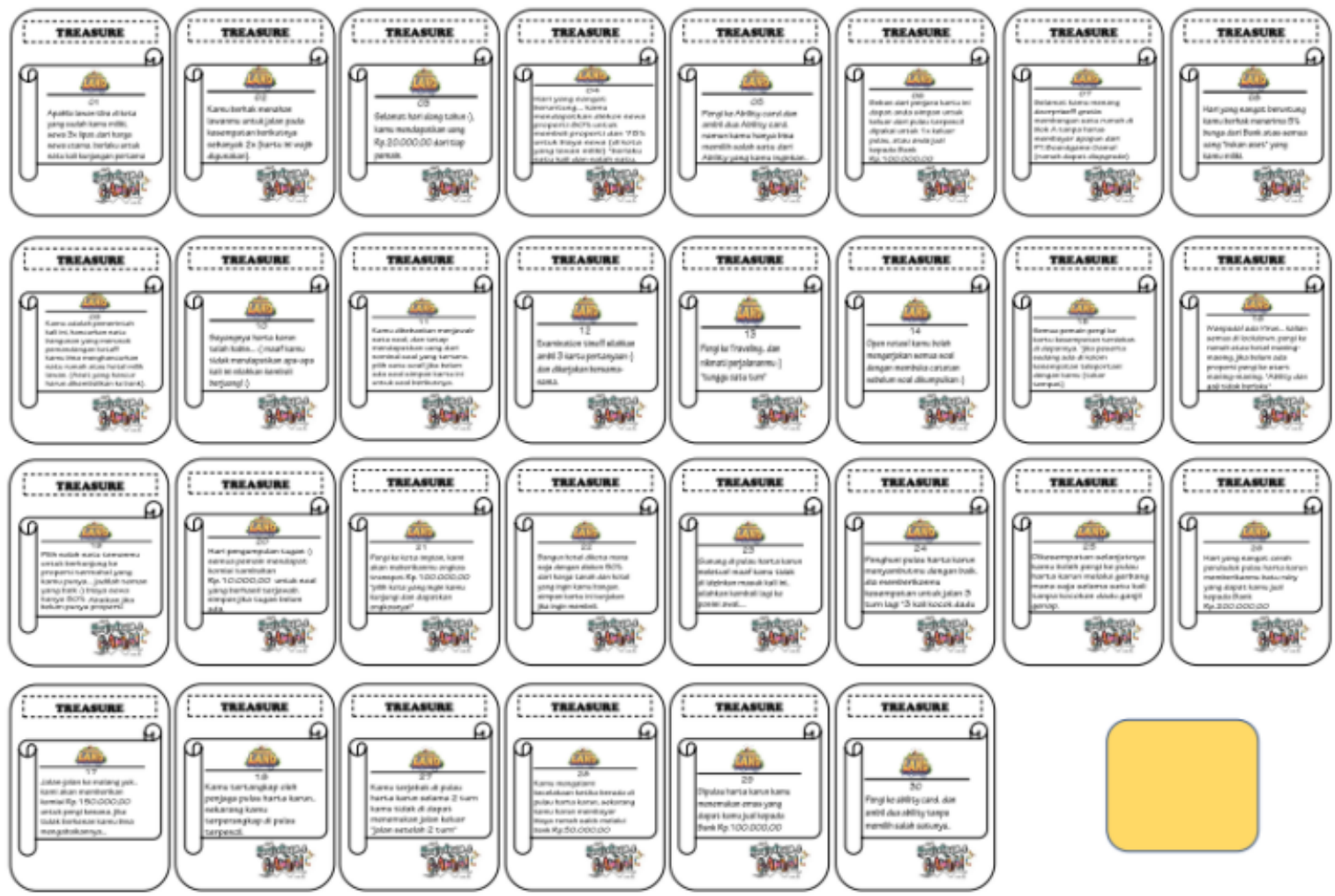

Gambar 4. Tampilan Kartu Treasure 


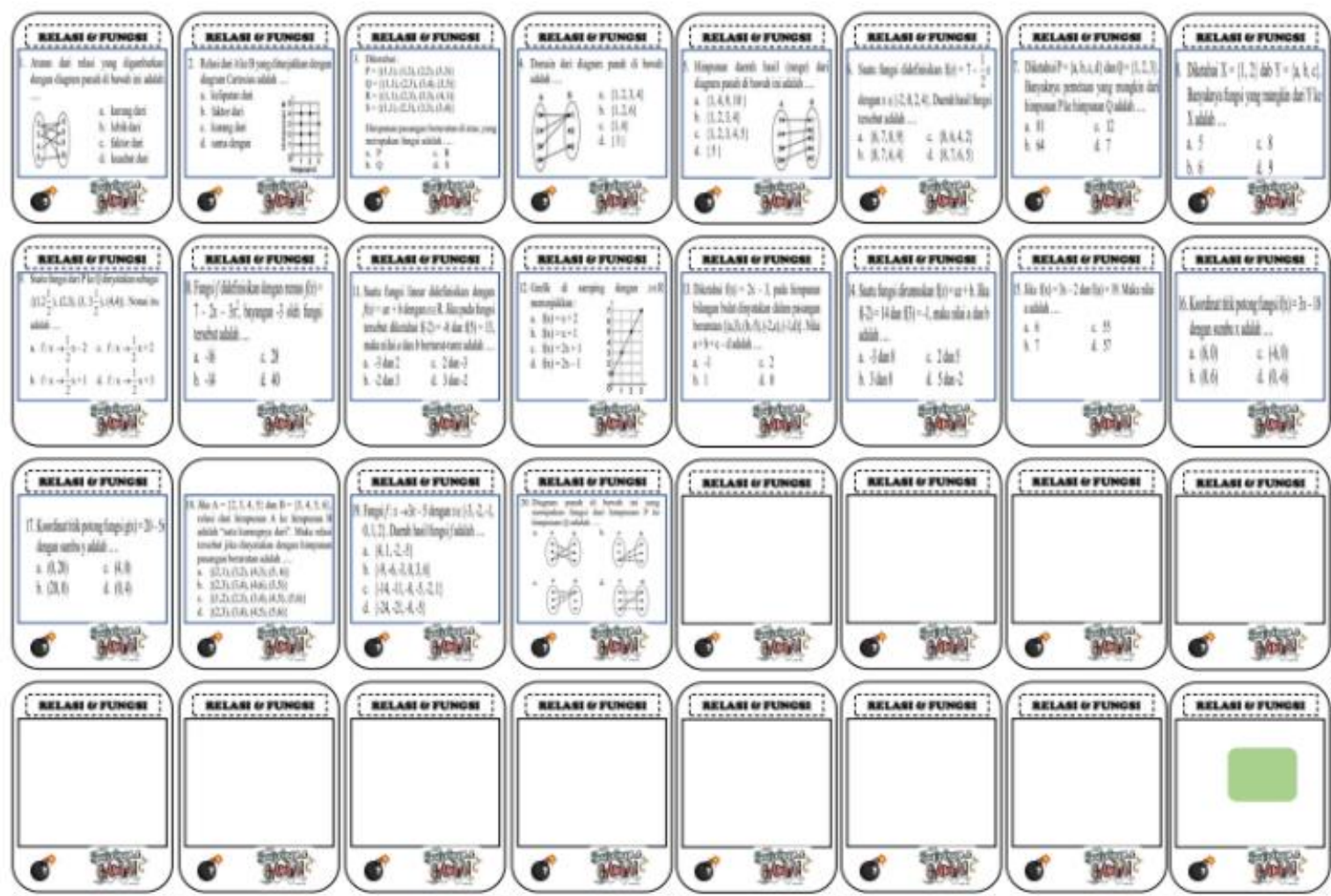

Gambar 5. Tampilan Kartu Pertanyaan

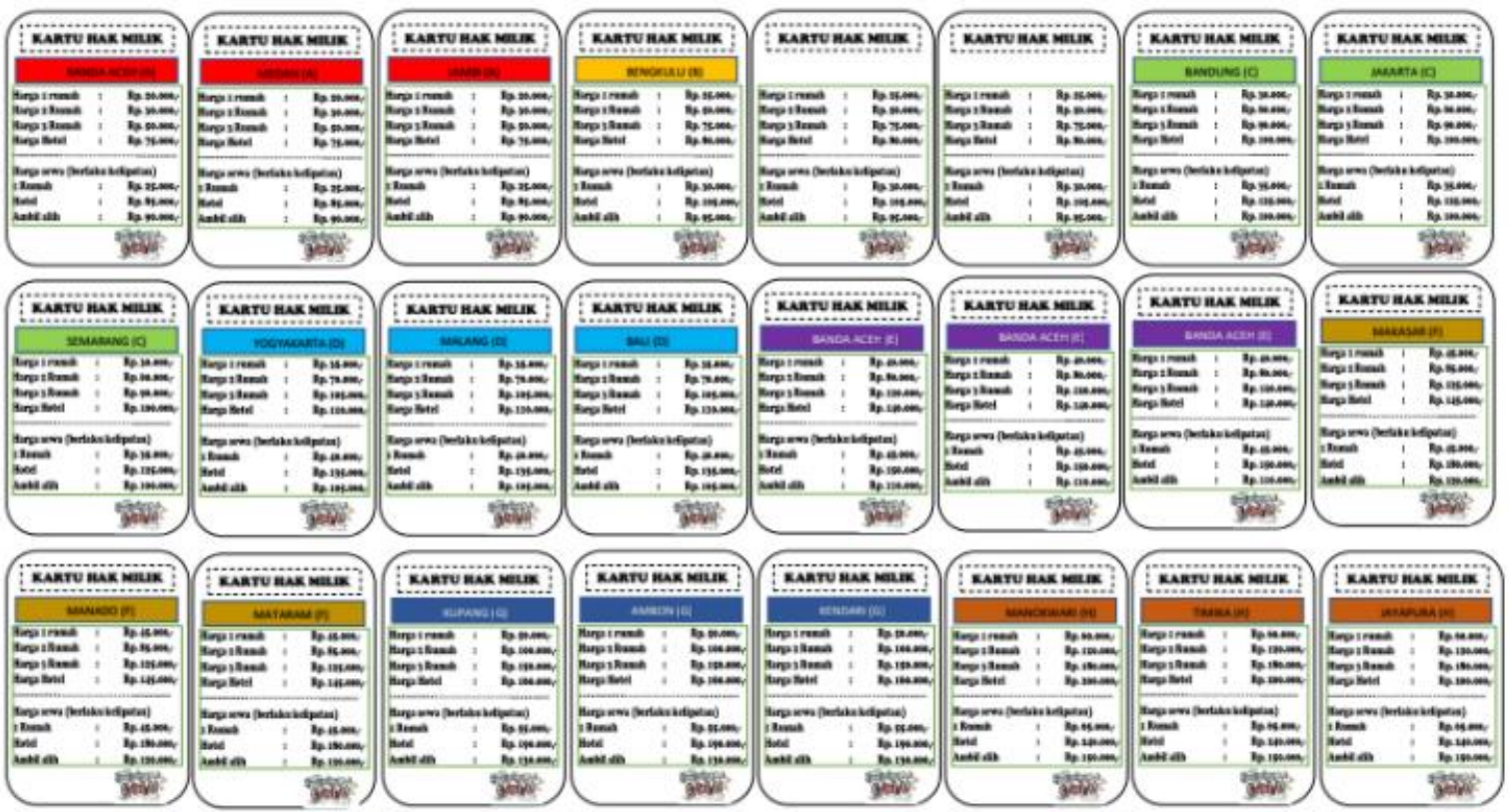

Gambar 6. Tampilan Kartu Hak Milik 


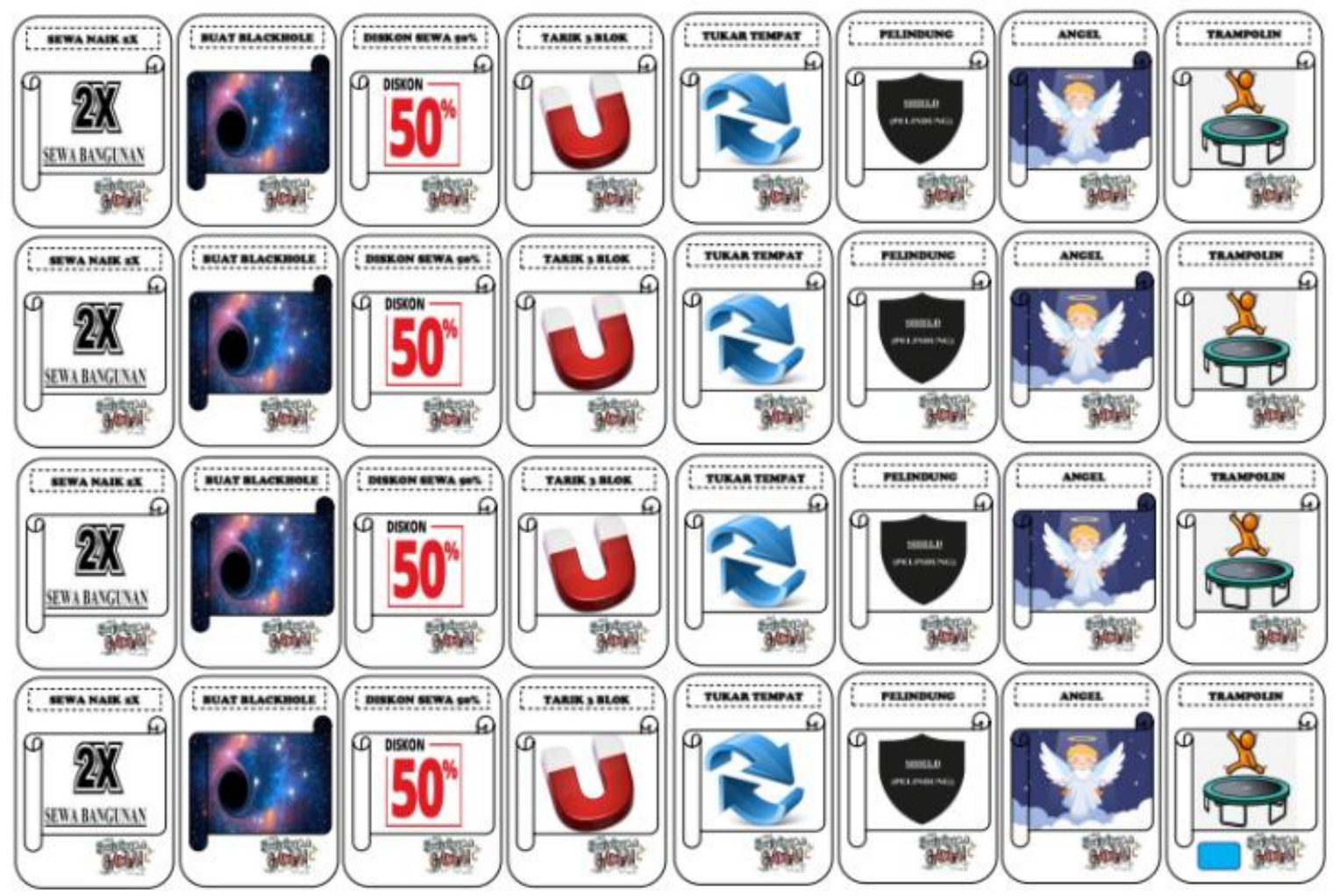

Gambar 7. Tampilan Kartu Petunjuk

5. Uji Coba Produk

Produk yang dihasilkan diuji cobakan sebelum diterapkan. Pengujian dilakukan untuk mendapatkan informasi tentang kelayakan dan keefektifan produk media board game. Uji Coba produk dalam penelitian ini dibagi menjadi dua, yaitu: uji coba perorangan oleh 3 orang peserta didik, dan uji coba kelompok kecil sebanyak 6 orang peserta didik kelas VIII SMP Negeri 48 Jakarta.

Berdasarkan perhitungan hasil uji coba perorangan dan uji coba kelompok kecil pada kelompok kontrol dan kelompok eksperimen dari kelas VIII SMP Negeri 48 Jakarta diperoleh $t$ hitung dengan harga $t_{o}=8,404$ sedangkan d.b $=33$ dengan taraf signifikansi harga kritis pada $\mathrm{t}_{0,05}=2,048$.

Dari hasil uci coba tersebut dilakukan revisi produk, karena beberpa soal dalam kartu pertanyaan terdapat kesalahan penulisan kata.

6. Revisi Produk

Revisi produk pertama kali dilakukan setelah diadakannya uji coba perorangan apabila terdapat masukan. Setelah itu revisi kedua terdapat masukan dari uji coba kelompok kecil.

7. Uji Coba Pemakaian

Setelah revisi produk dilakukan, maka dilakukan uji coba produk terdapat peserta didik pada kelompok besar yaitu dalam satu kelas yang terdiri dari 25 peserta didik. Hal ini dilakukan untuk mengetahui apakah produk layak dan efektif digunakan dalam pembelajaran.

Berdasarkan perhitungan hasil pre-test dan post-test pada kelompok kontrol dan kelompok eksperimen dari kelas VII SMP Negeri 48 Jakarta diperoleh t hitung dengan harga $t_{o}=15,337$ sedangkan d.b $=33$ dengan taraf signifikansi harga kritis pada $\mathrm{t}_{0,05}=2,034$.

Jadi dapat disimpulkan berdasarkan hasil uji coba tersebut ditemukan bahwa harga $t_{o}$ lebih besar dari harga $t_{0,05}$ yaitu 15,337 > 2,034. Hal ini menunjukkan bahwa 
penggunaan media board game pada kelompok eksperimen dapat meningkatkan efektifitas belajar peserta didik pada mata pelajaran Matematika Materi Pokok Semester 1 Kurikulum 2013 di SMP Negeri 48 Jakarta.

\section{Revisi Produk}

Revisi produk dilakukan apabila dalam pemakaiannya terdapat kekurangan atau kelemahan yang didapatkan setelah uji coba produk terhadap kelompok besar. Hal ini dilakukan agar mengetahui kelemahan-kelemahannya untuk menyempurnakan produk.

\section{Pembahasan}

Penelitian pengembangan ini menghasilkan sebuah produk Board Game berupa media tiga dimensi. Produk board game ini diperuntukkan untuk peserta didik kelas VIII SMP Negeri 48 Jakarta. Tujuan dari pengembangan board game ini adalah untuk mengasah kemampuan siswa dalam menyelesaikan soal matematika materi pokok semester 1 kelas VIII Kurikulum 2013 di SMP Negeri 48 Jakarta, dimana materi yang dibahas mengenai kecerdasan kognitif, afektif dan psikomotorik peserta didik pada mata pelajaran Matematika.

Setelah melalui tahapan yang sesuai dengan model pengembangan $R \& D$ oleh Sugiyono, pengembangan media board game ini sudah dikatakan layak dan efektif digunakan dalam proses pembelajaran kelas VIII SMP Negeri 48 Jakarta. Berikut adalah pembahasan dari data-data hasil uji coba dan revisi yang didapatkan, yaitu:

1. Data yang diperoleh dari uji kelayakan rencana pelaksanaan pembelajaran yang dilakukan oleh ahli desain rencana pelaksanaan pembelajaran mendapatkan persentase sebesar $87,5 \%$. Berdasarkan penilaian tersebut dapat dikatakan bahwa rencana pelaksanaan pembelajaran yang digunakan untuk mengembangkan board game materi pokok matematika mendapatkan nilai yang sangat baik dan layak digunakan dalam pengembangan board game matematika materi pokok semester 1 kelas VIII Kurikulum 2013.

2. Data yang diperoleh dari uji kelayakan materi yang dilakukan oleh ahli materi mendapatkan persentase sebesar $100 \%$. Berdasarkan penilaian tersebut maka dapat dikatakan bahwa penyusunan materi yang dimuat dalam kartu pertanyaan board game matematika materi pokok semester 1 kelas VIII Kurikulum 2013 memiliki nilai yang sangat baik dan layak untuk dikembangkan dalam sebuah media pembelajaran.

3. Data yang diperoleh dari uji kelayakan media oleh ahli media mendapatkan persentase sebanyak 93,33\%. Berdasarkan penilaian tersebut dapat dikatakan media board game materi pokok greeting and introduction memiliki nilai sangat baik dan layak untuk digunakan dalam proses pembelajaran.

4. Data yang diperoleh dari uji kelayakan bahan penyerta media oleh ahli bahan penyerta media mendapatkan persentase sebesar 95\%. Berdasarkan penilaian tersebut maka dapat dikatakan bahwa bahan penyerta yang dimuat dalam board game matematika materi pokok semester 1 kelas VIII Kurikulum 2013 memeiliki nilai yang baik dan layak digunakan sebagai bahan penyerta media board game materi pokok matematika kelas VIII Kurikulum 2013.

5. Data yang diperoleh dari instrumen angket media peserta didik mendapatkan persentase uji perorangan sebesar 91,11\%, uji kelompok kecil sebesar 83,33\% dan uji kelompok besar yaitu $94,4 \%$. Dimuat dalam board game matemtika materi pokok semester 1 kelas VIII Kurikulum 2013 memiliki nilai sangat baik dan layak digunakan sebagai kelayakan media media board game materi pokok matematika kelas VIII Kurikulum 2013. 


\section{Hasil Penelitian Kelayakan Media}

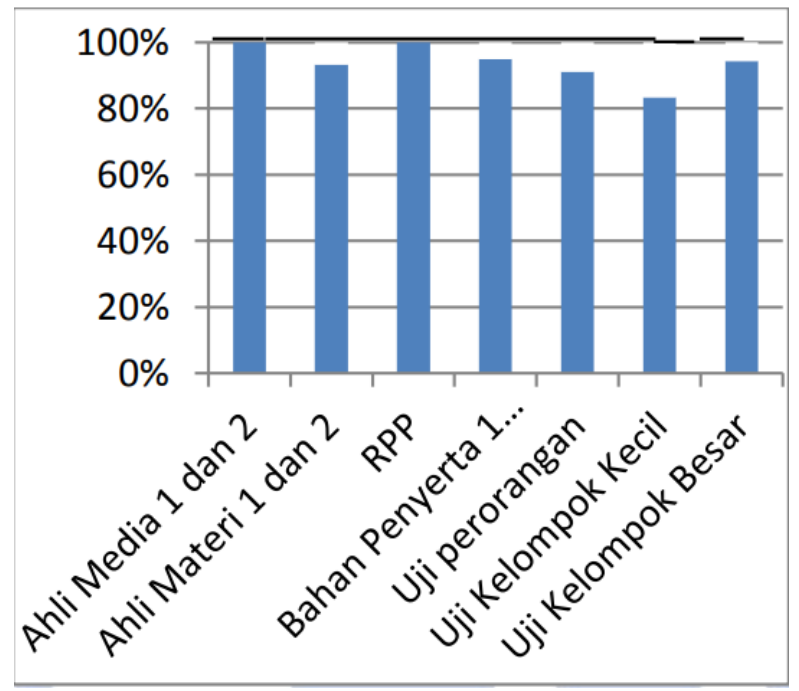

Gambar 8. Diagram Hasil Penilaian Kelayakan Media Board Game Matematika Materi Pokok Semester 1 Kelas VIII Kurikulum 2013 oleh Ahli dan Peserta Didik

6. Data hasil perbandingan pre-test dan post-test antara kelompok kontrol dan kelompok eksperimen membuktikan adanya perbedaan yang siginifikan yang diakibatkan oleh perlakuan media board game matemtika materi pokok semester 1 kelas VIII Kurikulum 2013 dengan perbandingan rata-rata kelompok untuk kelompok kontrol sebesar 56,17 sedangkan rata-rata kelompok eksperimen sebesar 83,52. Sehingga dapat disimpulkan bahwa media board game matematika materi pokok semester 1 kelas VIII Kurikulum 2013 untuk kelas VIII SMP Negeri 48 Jakarta.

\section{Hasil Penelitian Keefektifan Media}

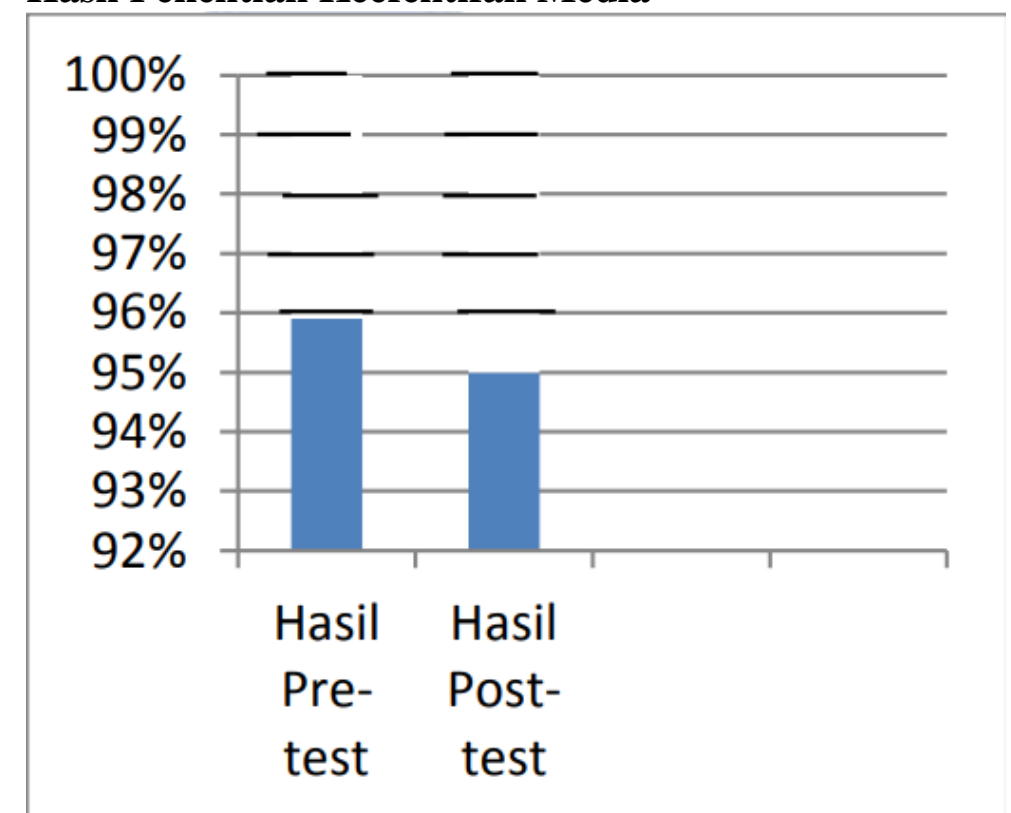

Gambar 9. Diagram Hasil Penilaian Keefektifan board game matemtika materi pokok semester 1 kelas VIII Kurikulum 2013 oleh Peserta Didik 


\section{KESIMPULAN}

Kesimpulan yang dapat kita ambil dari kegiatan penelitian ini adalah :

1. Perlu adanya metode yang lebih menyenangkan untuk menyampaikan materi pelajaran matematika di SMP Negeri 48 Jakarta. Cara yang dilakukan yakini dengan menciptakan suatu metode pembelajaran yang melibatkan siswa berinteraksi langsung dengan cara belajar sambil bermain yaitu dengan Board Game Matematika ini.

2. Penggunaan Board Game Matematika sangat membantu para guru matematika di SMP Negeri 48 Jakarta untuk dapat lebih berinteraksi dengan peserta didiknya dan menyampaikan materi matematika dengan cara yang lebih menyenangkan.

3. Perlu adanya tindak lanjut untuk memaksimalkan pengembangan produk Board Game Matematika ini. Karena kemajuan teknologi makin berkembang pesat diaharapkan Board Game Matematika ini diharapkan dapat menyesuaikan dengan kondisi dan kemajuan teknologi.

Demikian kesimpulan yang saya dapatkan mudah-mudahan hasil penelitian ini dapat bermanfaat dan memperbaiki kualitas pembelajaran di kelas baik bagi guru matematika di SMP Negeri 48 Jakarta maupun peserta didik SMP Negeri 48 Jakarta dalam mempelajari matematika materi semester 1 kurikulum 2013.

\section{DAFTAR PUSTAKA}

Acharya, B. R. (2017). Factors affecting difficulties in learning mathematics by mathematics learners. International Journal of Elementary Education, 6(2), 8-15.

Kristanto, A. (2010). PENGEMBANGAN MEDIA MODUL MATERI PENGGUNAAN ARRAY MATA PELAJARAN PEMROGRAMAN DASAR KELAS $\mathrm{X}$ MULTIMEDIA DI SMK NEGERI 1 JATIREJO. Jurnal Mahasiswa Teknologi Pendidikan, 9(2).

Kristanto, A., Mariono, A., \& Nuryati, D. W. (2018). Developing Media Module Proposed to Editor in Editorial Division. In Journal of Physics: Conference Series (Vol. 947, No. 1, p. 012054). IOP Publishing.

Miarso, Y. (2004). Menyemai benih teknologi pendidikan. Kencana.

Prameshela, R. Y., Kristiyanto, W. H., \& Mampouw, H. L. (2021). Developing Ardgotic Game to Improve Logarithm Learning Outcomes. International Journal of Active Learning, 6(2), 58-64.

Rahaju, R., \& Hartono, S. R. (2015). Pembelajaran Matematika Berbasis Permainan Monopoli Indonesia. JIPMat, 2(2).

Rohana, R., Hartono, Y., \& Purwoko, P. (2009). Penggunaan Peta Konsep dalam Pembelajaran Statistika Dasar di Program Studi Pendidikan Matematika FKIP Universitas PGRI Palembang. Jurnal Pendidikan Matematika, 3(2), 92-102.

Setyanugrah, F., \& Setyadi, D. I. (2017). Perancangan board game sebagai media pembelajaran mitigasi kebakaran untuk anak sekolah dasar usia 8-12 tahun di Surabaya. Jurnal Sains dan Seni ITS, 6(1), F62-F68. 